\title{
Polycyclic aromatic hydrocarbons (PAHs) in fine fractions of Barapukuria coal in Bangladesh
}

\author{
H. M. Z. Hossain ${ }^{1,2 *}$ and Q. H. Hossain ${ }^{2}$ \\ ${ }^{1}$ Department of Petroleum and Mining Engineering, Jashore University of Science and Technology, Jashore 7408, Bangladesh \\ ${ }^{2}$ Department of Geoscience, Shimane University, 1060 Nishikawatsu, Matsue 690-8504, Japan
}

Received: 20 June 2018

Revised: 15 October 2018

Accepted: 03 December 2018

DOI: $10.3329 /$ bjsir.v54i3.42672

\begin{abstract}
The existence and distribution of polycyclic aromatic hydrocarbons (PAHs) in fine coal fractions have been determined in order to evaluate their potential carcinogenicity to human beings. Thirteen PAHs of fine coal fractions $(n=9)$ from Barapukuria coal field, situated at the northwestern part of Bangladesh were analyzed by the gas chromatography-mass spectrometry (GC-MS) method in order to examine their distributions and toxicity in the environment. Relative abundances of fluoranthene (Flu), pyrene (Pyr), benzo $[b, j, k]$ fluoranthene (Bflas), benzo $[e]$ pyrene $(\mathrm{BeP})$ and benzo $[a]$ pyrene $(\mathrm{BaP})$ were found to be high, followed by phenanthrene (Phe), indeno $[1,2,3-c d]$ pyrene (InP), benzo $[g, h, i]$ perylene (BghiP) and coronene (Cor). The average loads of carcinogenic PAHs in the fine coal fractions decreased in the order: $\mathrm{Bflas}>\mathrm{BeP}>\mathrm{BaP}>\mathrm{BghiP}>\mathrm{InP}>$ Cor. The $\mathrm{PAHs}$ ratios of $\mathrm{BeP} /(\mathrm{BeP}+\mathrm{BaP})$ ranging from 0.61 to 0.85 (average 0.74 ), reflected the decay of $\mathrm{BaP}$ due to ageing in prolonged exposure to the solar radiation. High abundance of land plant markers retene (Ret) and Phe and $\mathrm{BaP} /$ BghiP ratio $(\sim 0.10$ to 6.16 , average 1.89$)$ values indicate that organic matters in the studied samples were derived from typical biological sources. Moreover, the existence of more middle- and higher molecular weight (MMW and HMW) PAHs over lower molecular weight (LMW) PAHs in most samples implied the association of high toxicity with negative impacts on human health. The health risk assessment factors $\left(\mathrm{BaP}_{\mathrm{eg}}\right)$ ranging from $0.55 \mathrm{ng} \mathrm{g}^{-1}$ to $6.51 \mathrm{ng} \mathrm{g}^{-1}$ indicates moderate to high health risk related to carcinogenic PAHs in the surrounding atmosphere. The estimated incremental lifetime cancer risk (ILCR) values for adults $\left(9.96 \times 10^{-5}\right.$ to $\left.1.27 \times 10^{-4}\right)$ and children $\left(5.56 \times 10^{-6}\right.$ to $\left.1.12 \times 10^{-6}\right)$ were found to be higher than or equal to the range of $1.0 \times 10^{-6}$ to $1.0 \times 10^{-4}$.
\end{abstract}

Keywords: Polycyclic aromatic hydrocarbons (PAHs); Coal fractions; Source identification; Health risk assessment; Bangladesh

\section{Introduction}

Polycyclic aromatic hydrocarbons (PAHs) are common toxic organic chemicals composed of two or more fused benzene rings arranged in different configurations (Chefetz et al., 2000; Kim et al., 2013; Wu et al., 2014; Hu et al., 2017). PAHs can comprise extra fused rings those are not six-sided. Some representative structures, formula, physicochemical properties and existence in either particle or gas phase are shown in Table 1. The presence of PAHs in natural environment is largely generated during incomplete combustion or pyrolysis of organic materials from both natural and anthropogenic sources (Omar et al., 2006; Ravindra et al., 2008; Li et al., 2016). The natural sources of
PAHs are likely emissions from forest fires and volcanic eruptions (Ravindra et al., 2008; Jamhari et al., 2014), whereas anthropogenic sources of PAHs and their alkyl derivatives are constituents of crude oil, refined petroleum products and industrial chemicals, power plants, waste incineration and coal/biomass burning (Vicente et al., 2015). Several PAHs are also originated from transformation by photolysis, photochemical, thermochemical reactions and oxidation of biological materials (Boström et al., 2002; Bandowe and Nkansah, 2016). However, PAHs are released mostly into the atmosphere, present as gases or in fine particulate matter (e.g. coal dust, street dust etc.) (Wu et al., 
2014; Bandowe and Nkansah, 2016; Lui et al., 2017). In general, PAHs are known to have mutagenic, genotoxic, carcinogenic and estrogenic properties, and their physicochemical properties are highly mobile in the environment via air, soil and water bodies (Boström et al., 2002; Kim et al., 2013; Wincent et al., 2016; Hu et al., 2017; Lui et al., 2017). PAHs in the atmospheric environment behave equal to persistent organic pollutants continue to undergo long-range atmospheric transport (Fang et al., 2004; Mulder et al., 2015; Liu et al., 2017). However, reaction half-lives of persistent organic pollutants in water, soil, and sediments are much higher than in the atmospheric gaseous phase. Recently, atmospheric PAHs have received great attention in air pollution studies globally owing to its high levels of toxicants those are harmful for most city dwellers (Fang et al., 2004; Kim et al., 2013; Jamhari et al., 2014; Hu et al., 2017; Lui et al., 2017).

Coal is solid fossil fuels that are omnipresent in sedimentary rock strata. The Permian Gondwana sequence in northwestern Bangladesh contains abundant coals and coaly shales. The coal-bearing Barapukuria basin, covering an area of approximately $6.68 \mathrm{~km}^{2}$ (Wardell-Armstrong, 1991; Bakr et al., 1996; Annual Report, 2017), is located in the Rangpur platform of the Stable Shelf zone in northwestern Bangladesh (Fig. 1). This area lies between the latitudes $25^{\circ} 31^{\prime} 45^{\prime \prime}$ to $25^{\circ} 33^{\prime} 50^{\prime \prime} \mathrm{N}$ and the longitudes $88^{\circ} 57^{\prime} 48^{\prime \prime}$ to $88^{\circ} 58^{\prime} 53^{\prime \prime} \mathrm{E}$ (Tahsin et al., 2016). A total geological coal reserve is estimated to be 390 million tons in the Barpukuria coal basin (Annual Report, 2017). Approximately 4,500 metric tons of coal is extracted every day from coal face no. 1207 within the coal seam VI (Fig. 1b) of the Barapukuria coal mine (Annual Report, 2017), which is mainly used in coal based power plant, brick industry and domestic cooking purposes. Huge amount of fine coal particles are generated during coal extraction from underground coal cutting phase, coal transport and coal storage in an open place in the coal mine area. These fine fractions are often mixed with inside and outside environments via inlet or outlet mine ventilation system to air, soil, and running water that are highly carcinogenic and posing high risk to humans (e.g. pneumoconiosis, lung diseases, chronic obstructive pulmonary disease) from short- and long-time inhaling those fine particles from surrounding atmosphere. Several authors have investigated coal and coal-bearing Gondwana sequence in northwestern Bangladesh from different points of view

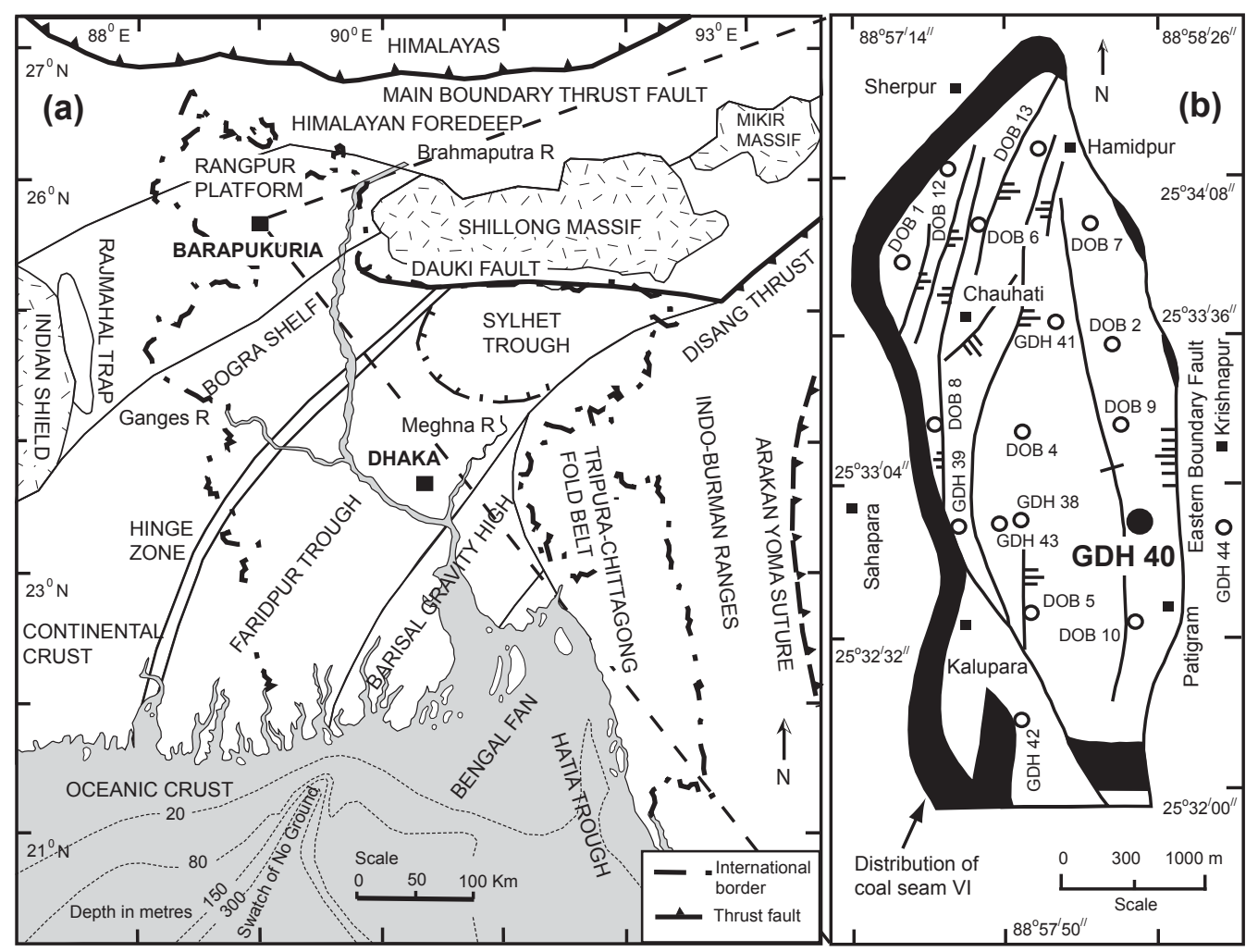

Fig. 1. (a) Location map of the Barapukuria basin and surrounding areas (after Hossain et al., 2013b, 2019) and (b) Distribution of coal seam VI in the Barapukuria basin, northwestern Bangladesh (after Bakr et al., 1996) 
such as lithofacies, stratigraphy, sedimentology, geochemistry, petrography and many others (e.g. Wardell-Armstrong, 1991; Uddin and Islam, 1992; Bakr et al., 1996; Islam, 1993, 1994, 2002; Hossain et al., 2002, 2013; Islam et al., 2004; Tahsin et al., 2016). So far no study has been conducted using this fine coal particle to address toxicity and long term cancer risk to humans. So, the present study has been conducted for exploring toxic PAHs in fine coal fractions of Bangladesh, and for assessing the harmful impact into the atmospheric environments.

\section{Materials and methods}

\section{Sampling}

This study was conducted in Barapukuria coal field area, the only one underground coal mine in Bangladesh which is situated in Dinajpur district, northwestern part of Bangladesh. A total of nine samples of fine coal fractions were collected from the Barapukuria coal mine area during dry season (Fig. 1). The samples were stored in polythene bags (Ziploc) subsequently sealed and transport to the laboratory. All samples were then air dried at room temperature to constant weight and homogenized by grinding in an agate mortar and pestle.

All the fine powdered samples were used for solvent extraction of bitumen. Approximately $5 \mathrm{~g}$ powdered samples were extracted using Soxhlet apparatus with a mixture of dichloromethane (DCM) and $\mathrm{MeOH}$ solution (9:1) for $72 \mathrm{~h}$. Activated copper granules were added to remove elemental sulfur from the solutions. The extracted solvent was removed using a rotary vacuum evaporator (Hossain et al., 2013a). The $n$-alkanes and PAHs were separated using thin layer chromatography over activated silica gel (Kiselgel 60 PF254, Merck). The extracts were transferred into two ampoule bottles and stored in a refrigerator until analysis in the laboratory.

The fractions containing the PAHs were subjected to analyze by a gas chromatography (GC: Shimadzu QP2010) coupled with a mass spectrometry (MS: Shimadzu GCMS-QP2010) instrument through filtration by $0.45 \mu \mathrm{m}$ filters. The GC is equipped with a programmable temperature injection system and a fused silica capillary column $(30 \mathrm{~m} \times 0.25 \mathrm{~mm} \mathrm{ID}$, DB-5MS, Agilent Technology), with a temperature program of $50-300{ }^{\circ} \mathrm{C}$ at a rate of $8{ }^{\circ} \mathrm{C} / \mathrm{min}$. Helium with a purity of $99.999 \%$ is used as the carrier gas. The MS is operated in electron impact ionization mode with an ion source temperature of $250^{\circ} \mathrm{C}$ and the electron impact energy is set at $70 \mathrm{eV}$. All spectra were recorded over a range of 50 to 850 $\mathrm{m} / \mathrm{z}$ at a scan rate of $0.5 \mathrm{~s}$. Quantification of PAHs is standardized by the comparison of $\mathrm{GC}$ retention times, mass spectra with published data and with standard PAHs Solution Mix (Accu Standard Inc. Z-013-17).

In this study, thirteen PAHs are identified and estimated, such as phenanthrene (Phe, $m / z=178$ ), anthracene (Ant, $m / z=$ 178), fluoranthene (Flu, $m / z=202)$, pyrene $(\mathrm{Pyr}, m / z=202)$, retene (Ret, $m / z=219)$, benzo[ $a]$ anthracene $(\mathrm{BaA}, m / z=$ 228), chrysene (Chry, $m / z=228$ ), benzo[ $b, j, k]$ fluoranthene (Bflas, $m / z=252$ ), benzo[e]pyrene (BeP, $m / z=252$ ), benzo $[a]$ pyrene $(\mathrm{BaP}, m / z=252)$, indeno[ $[1,2,3-c d]$ pyrene (InP, $m / z=276$ ), benzo[ $g, h, i]$ perylene (BghiP, $m / z=276$ ) and coronene (Cor, $m / z=300$ ). The PAHs are classified based on the number of aromatic rings present in the individual compound such as 2-ring (Naphthalene), 3-ring (Phe, Ant), 4-ring (Flu, Pyr, BaA, Chry), 5-ring (Bflas, BeP, BaP), 6-ring (InP, BghiP), and 7-ring (Cor). Naphthalene was not identified in this study. On the basis of aromatic rings number, investigated PAHs are also categorized as lower molecular weight PAHs (LMW, containing 2- to 3-rings PAHs), middle molecular weight PAHs (MMW, containing 4-ring PAHs), and higher molecular weight PAHs (HMW, containing 5- to 7-rings PAHs).

\section{Human health risk assessment of PAHS}

Health risk assessment model was used to evaluate carcinogenic and non-carcinogenic threat obtained from different exposure pathways (USEPA, 1989). Health risk can be calculated using PAHs exposure in the environment through ingestion, inhalation and/or dermal exposure (Jamhari et al., 2014; Kong et al., 2015; Li et al., 2016; Hu et al., 2017). BaP equivalent concentration $\left(\mathrm{BaP}_{\mathrm{eq}}\right)$ was also adopted to assess the health risk of PAHs (Kong et al., 2015; Li et al., 2016). The $\mathrm{BaP}_{\mathrm{eq}}$ was estimated by multiplying the mass concentrations of individual PAH species of their corresponding toxic equivalency factors as follows:

$\mathrm{BaP}_{\text {eq }}=0.001(\mathrm{NaP}+\mathrm{Ace}+\mathrm{Flu}+\mathrm{Phe}+\mathrm{Fl}+\mathrm{Pyr})+0.01$ $($ Ant + Chry + BghiP $)+0.1(B a A+$ Bflas + InP $)+B a P+$ DBA (1)

$\mathrm{NaP}$ (naphthalene), Ace (acenaphthene), Fl (fluorene), and DBA (dibenz $[a, h]$ anthracene) were not detected in the present study samples. However, $\mathrm{NaP}$ value for coaly shale sample in the Barapukuria basin was taken from Hossain et al. (2019). The Ace, Fl and DBA values were adopted from published literature (Jamhari et al., 2014; Wu et al., 2014).

The cancer risk can be assessed from direct inhalation of carcinogenic PAHs in the atmospheric environments (USEPA, 1989; Jamhari et al., 2014; Kong et al., 2015). The incremental lifetime cancer risks (ILCR) for human beings was calculated by the lifetime average daily dose (LADD) of 
PAHs based on USEPA guidelines (USEPA 1989, 2013; Wiriya et al., 2013; Jamhari et al., 2014; Kong et al., 2015; Li et al., 2016) as follows:

$$
\begin{aligned}
& \mathrm{LADD}=\mathrm{C} \times \mathrm{IR} \times \mathrm{ED} \times \mathrm{EF} /(\mathrm{BW} \times \mathrm{ALT}) \\
& \mathrm{ILCR}=\mathrm{LADD} \times \mathrm{CSF}
\end{aligned}
$$

where $\mathrm{C}$ is the mass concentration of PAHs in fine coal particles $\left(\mathrm{ng} \mathrm{g}^{-1}\right)$; IR is the inhalation rate $\left(\mathrm{m}^{3}\right.$ day $^{-1}, 20$ and 7.6 for adult and children, respectively); ED is the lifetime exposure duration (52 years for adult and 6 years for children); EF is the exposure frequency (250 days year ${ }^{-1}$ ); BW is the average body weight $(70 \mathrm{~kg}$ and $15 \mathrm{~kg}$ for adult and children, respectively); ALT is the average lifetime for carcinogens (70 years $\times 365$ days year ${ }^{-1}=25,550$ days $)$; and CSF is the carcinogenic slope factor $\left(1 /\left(\mathrm{mg} \mathrm{kg}^{-1} \mathrm{day}^{-1}\right)\right)$. In the present study, CSF value based on the cancer-causing ability of $\mathrm{BaP}$ is set as $3.85\left(1 /\left(\mathrm{mg} \mathrm{kg}^{-1} \mathrm{day}^{-1}\right)\right)$ for inhalation
(Hu et al., 2017). The total $\mathrm{BaP}_{\text {eq }}\left(\mathrm{ng} \mathrm{g}^{-1}\right)$ values are used to calculate LADD instead of C (Jamhari et al., 2014; Li et al., 2016).

\section{Results and discussion \\ PAHs ring number distributions and sources}

The distribution and possible source of PAHs and their influence in atmospheric environments can be found in different concentrations of LMW, MMW, and HMW PAHs existing in the studied environmental samples. Representative TIC (total ion current) chromatograms and average PAHs distributions of the studied samples are shown in Figs. 2 and 3. The relative abundance of 4- (Flu, Pyr) and 5-rings (Bflas, BeP) PAHs are considerably high, followed by 3- (Phe), 6- (InP, BghiP), and 7-rings (Cor) PAHs. The biological origin of Phe and Ret sets them at higher abundances, while combustion derived high molecular

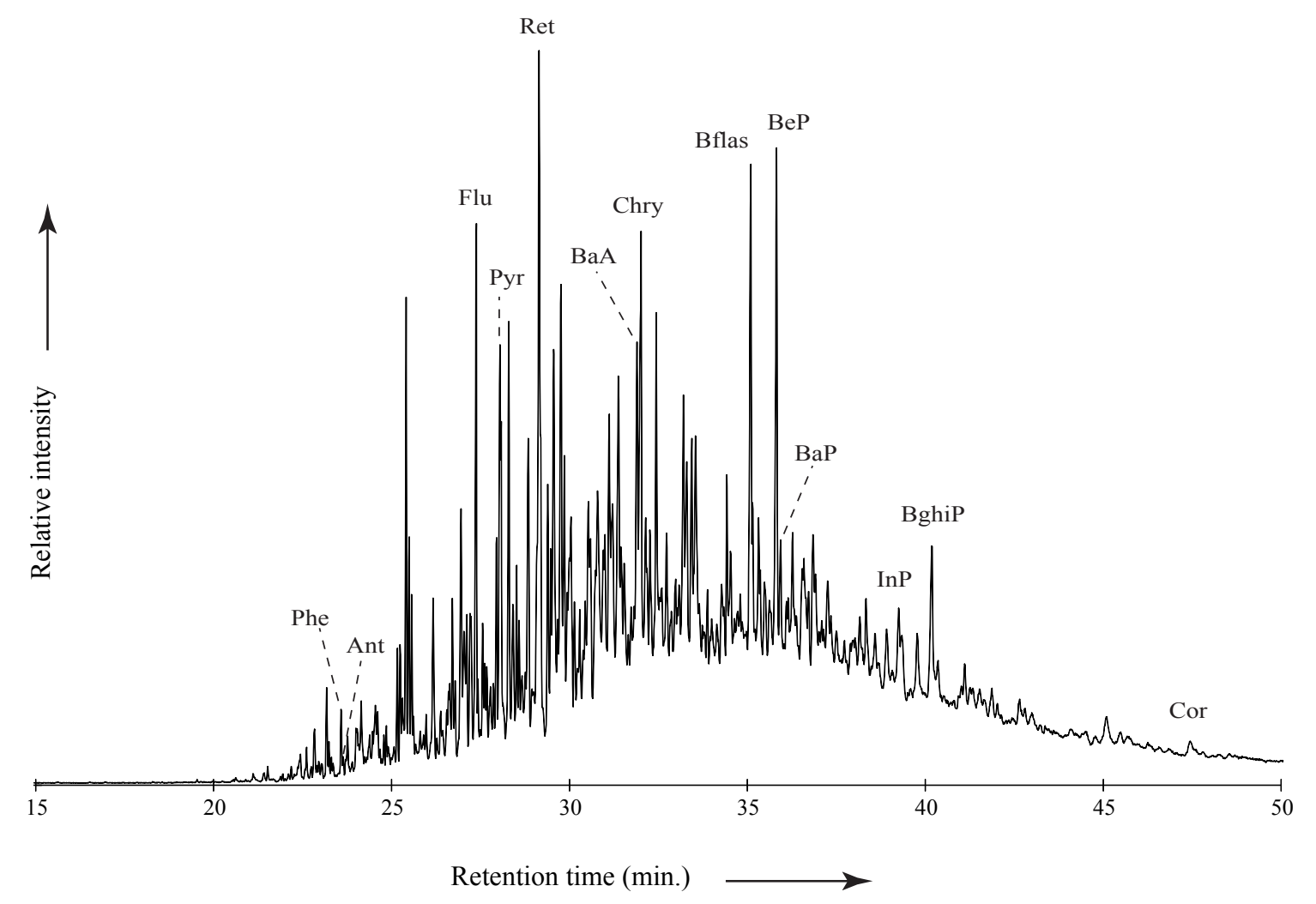

Fig. 2. Representative total ion chromatograms (TICs) of aromatic hydrocarbon fractions $(\mathrm{m} / \mathrm{z}, 57)$ of fine coal samples from the Barapukuria coal field, northwestern Bangladesh. Abbreviations: Phe, phenanthrene; Ant, anthracene; Flu, fluoranthrene; Pyr, pyrene; Ret, retene; BaA, benzo [a] anthracene; Chry, chrysene; Bflas, benzo $[b, j, k]$ fluoranthene; BeP, benzo $[e]$ pyrene; BaP, benzo $[a]$ pyrene; InP, indeno $[1,2,3-c d]$ pyrene; BghiP, benzo $[g, h, i]$ perylene; Cor, coronene 


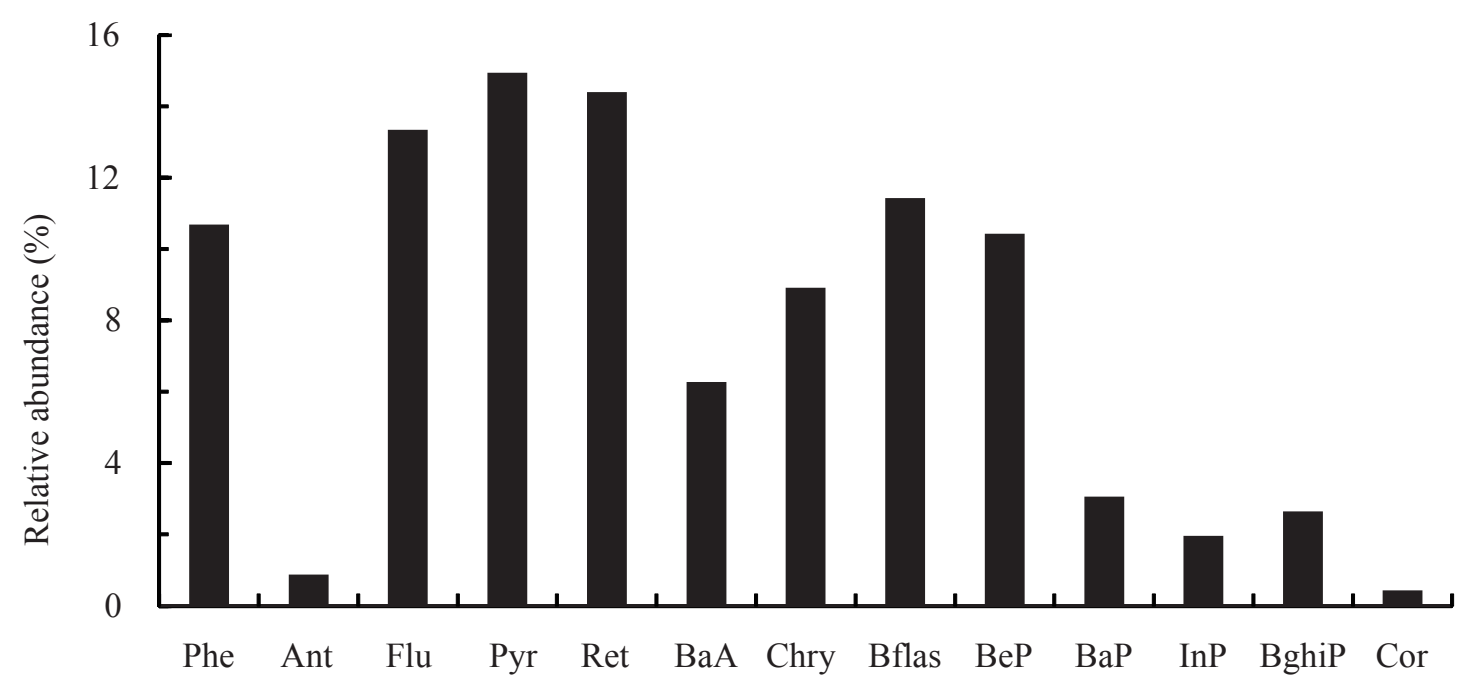

Fig. 3. Average relative abundance of PAHs for the studied fine coal fractions in Barapukuria coal field, northwestern Bangladesh

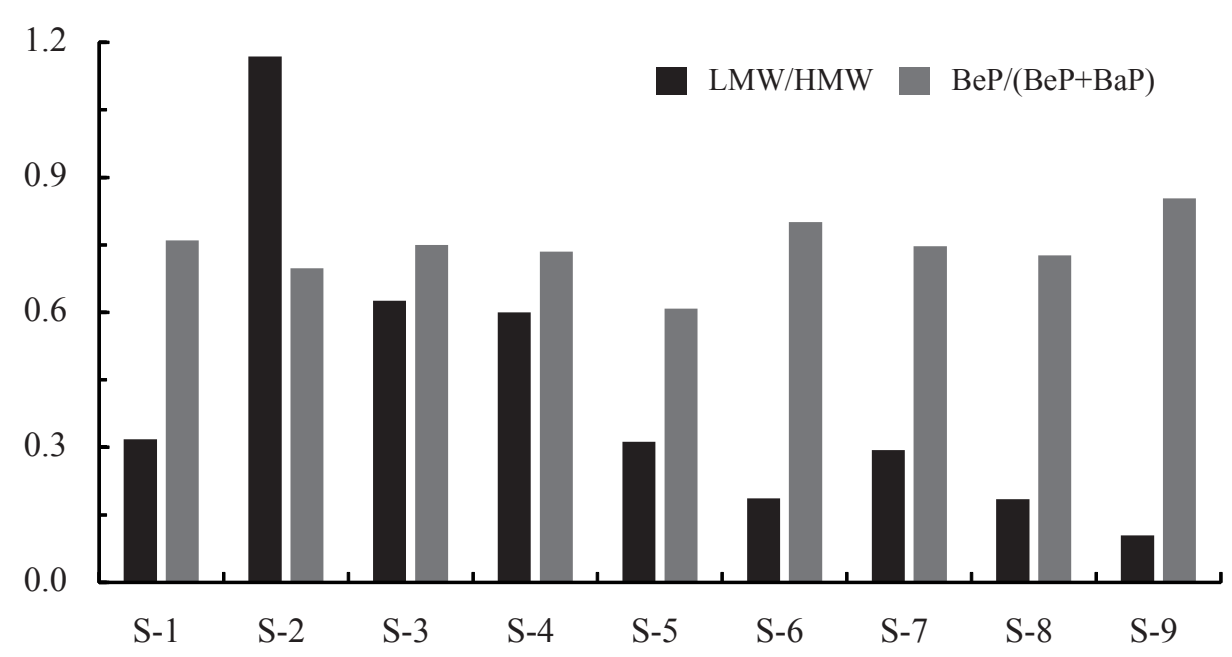

Fig. 4. Comparison of $\mathrm{LMW} / \mathrm{HMW}$ and $\mathrm{BeP} /(\mathrm{BeP}+\mathrm{BaP})$ ratios for each sample of the fine coal fractions in Barapukuria coal field, northwestern Bangladesh

weight PAHs (e.g. Cor) are present in low abundances (Fig. 2). However, average Phe loads are nearly identical to Bflas and $\mathrm{BeP}$, whereas Ant alone is two times higher than Cor. Meanwhile, average relative abundance of MMW PAHs is significantly higher than some compound of HMW PAHs in the samples studied (Fig. 3). The ratios of LMW/HMW PAHs in the samples ranged between 0.10 and 1.17, with high values in one sample (S-2, Fig. 4) and two samples contained
$>0.5$, and others fall below 0.5 (Fig. 4). These features suggest that some contrasts in source materials (diagenetic or combustion) exist between the samples, and their adverse human health effects in short- and long-time inhalation are discussed in sub-section 3.2.

Among the PAHs, LMW or MMW compounds are typically semi-volatile and partition in both the gas and particle phases 
(Table 1), while HMW compounds are highly non-volatile and retain commonly in the particle phase (Huang et al., 2006; Wu et al., 2014; Kong et al., 2015; Hu et al., 2017). Thus, LMH PAHs are more volatile than HMW PAHs, and has a larger ability to transport in the air phase systems as $\mathrm{Wu}$ et al. (2014) and Kong et al. (2015) noted that PAHs with LMW are mostly distributing in gas phase in the natural environments. PAHs originated from numerous sources, including combustion (both biomass and diagenetic alteration of natural biolipids), and emissions of non-combustion derived diagenetic processes (Chefetz et al., 2000; Yunker et al., 2011). The contribution of PAHs is mainly controlled by accessibility of biological yield and organic matter particle size, and organic matter stability through oxidative weathering, rock alteration, biodegradation and bioaccumulation, and long-run transport to sedimentary environments (Yunker et al., 2002; Marynowski et al., 2011). On the other hand, biomass burning and fossil fuel combustion of power plants, industries, residential cooking and vehicles are major sources of PAHs in the atmosphere due to their incomplete combustion or pyrosynthesis process (Omar et al., 2006; Ravindra et al., 2008; Jamhari et al., 2014; Kong et al., 2015). Moreover, PAHs with HMW (e.g. Bflas, BeP and Cor) are less susceptible to environmental transportation, oxidative modification and bacterial degradation (Jiang et al., 1998), while $\mathrm{BaA}$ and $\mathrm{BaP}$ are frequently degraded during those processes (Sicre et al., 1987; Yunker et al., 2002, 2011; Stout and Emsbo-Mattingly, 2008). Jamhari et al. (2014) reported that high concentrations of Flu, Pyr, BaA and Chry in the natural environmental samples are regarded as natural gas and coal combustion. The investigated coal fractions contained high relative abundances of Bflas, BeP, Flu, Pyr, BaA and Chry (Fig. 2), suggesting that these PAHs were originated primarily from combustion sources, leading to probable carcinogenic to humans. The relative abundances of total carcinogenic PAHs in individual samples are shown in Fig. 5. Most samples containing elevated level of carcinogenic PAHs $(>30 \%)$, indicating higher health risks from long-term PAHs exposure in the environment. Furthermore, large contributions of these PAHs in the Barapukuria coal mine areas may bear a worst health impact to the mine workers as well as nearby populations. Presence of high relative abundances of Phe and Ret in the studied coals suggests biological source materials input to the atmospheric environment.

5-ring PAHs such as $\mathrm{BaP}$ is more reactive than $\mathrm{BeP}$ in the

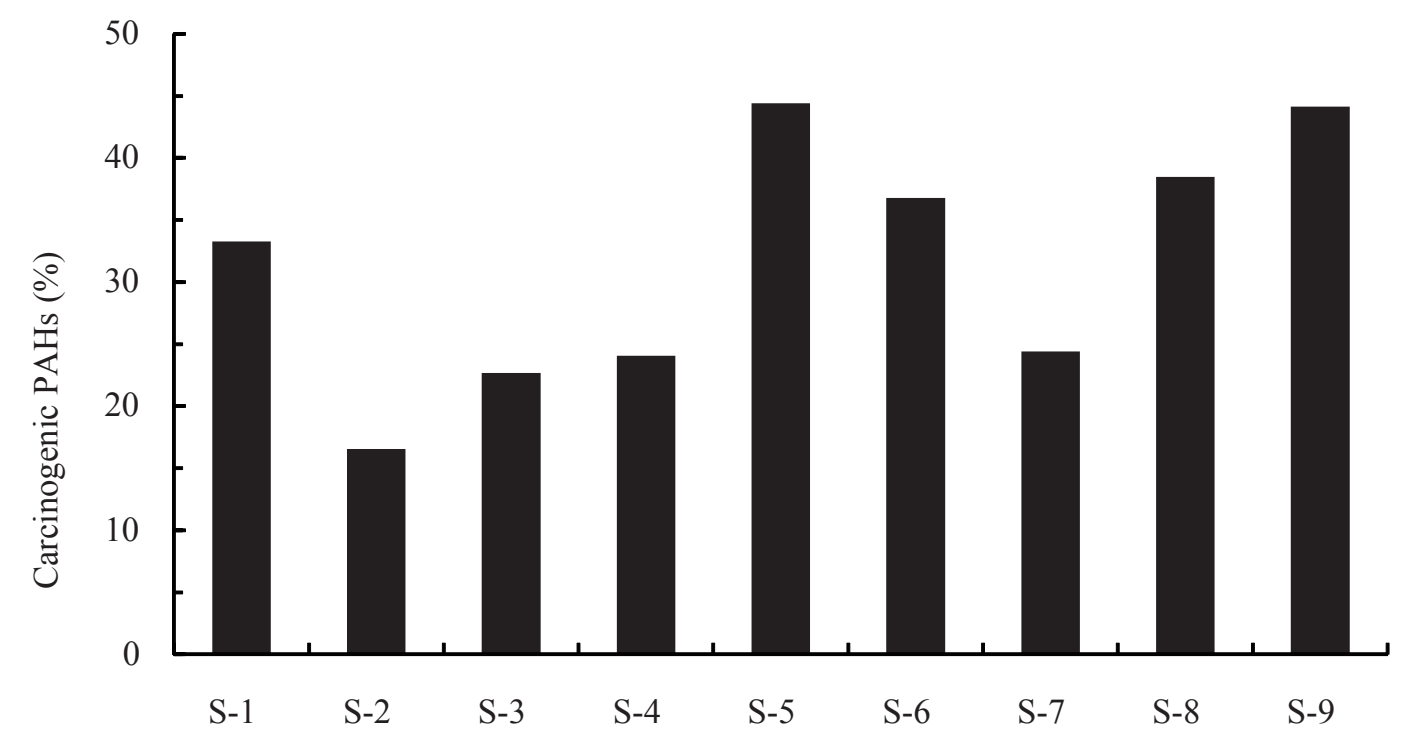

Fig. 5. Relative abundances (percentage) of carcinogenic PAHs for each sample of the fine coal fractions in Barapukuria coal field, northwestern Bangladesh 
atmospheric environment (Kong et al., 2015), and $\mathrm{BeP} /(\mathrm{BeP}$ $+\mathrm{BaP})$ ratio is remarked as an indicator of the aging process of aerosols (Huang et al., 2006; Omar et al., 2006). BaP is readily susceptible to photochemical oxidation in natural environment (Kong et al., 2015). Therefore, photochemical degradation of PAHs in the atmospheric environment might enriched $\mathrm{BeP} /(\mathrm{BeP}+\mathrm{BaP})$ ratio (Omor et al., 2006; Kong et al., 2015). The $\mathrm{BeP} /(\mathrm{BeP}+\mathrm{BaP})$ ratios in the investigated samples ranged from 0.61 to 0.85 (Fig. 4), reflecting decay of $\mathrm{BaP}$ due to aged and prolonged exposure to solar radiation (Nielsen, 1988; Omar et al., 2006). The significantly higher level of $\mathrm{BaP} / \mathrm{BghiP}$ ratios $(>1.25)$ in the atmosphere were suggested for residential heating and industrial operation of coal (Ravindra et al., 2008). Thus, the ratios of BaP/BghiP in the coal fractions studied are ranging from $\sim 0.70$ to 6.16 (average 1.89), and most of the samples have values $>1.25$ reflecting occurrence of coaly organic matter sources.

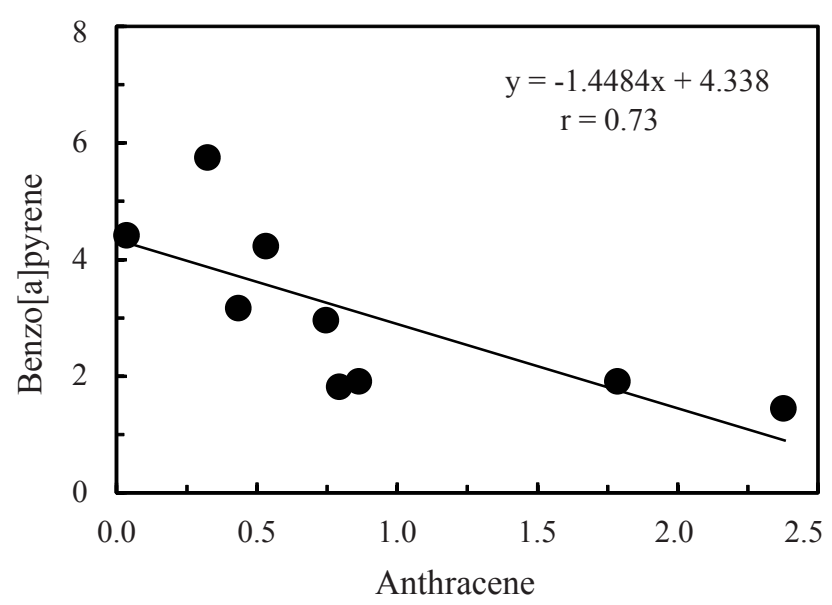

Fig. 6. Relationship between benzo[a]pyrene and anthracene of the studied fine coal fractions in Barapukuria coal field, northwestern Bangladesh

However, correlation between $\mathrm{BaP}$ and Ant in the studied samples is negative $(r=0.73)$ (Fig. 6), increasing BaP with decreasing Ant suggests that these PAHs might be originated from different sources.

\section{Environmental health risk assessment}

PAHs have adverse health effects from short- or long-term human exposure through breathing and/or skin contact in atmospheric environment (Omar et al., 2006; Kim et al., 2013). But atmospheric PAHs are partitioned between particulate matter and gas phase (Table I), they are commonly linked principally with particulate matter (Fang et al., 2004; Huang et al., 2006). The coaly particulate matters are widespread inside and outside atmosphere of the Barapukuria coal mine. This particulate material contains toxic PAHs that are being highly carcinogenic. Kim et al. (2013) suggested that mixtures of PAHs are extremely carcinogenic to human exposures than individual PAHs. Human exposure to PAHs and associated carcinogenicity has been tabulated in Table II. The probable human carcinogen PAHs includes BaA, BaP, Bflas, Chry, and InP (USEPA, 2008). Average abundances of these carcinogenic PAHs in the samples studied are in decreasing order as follows: Bflas $>\mathrm{BeP}>\mathrm{BaP}>\mathrm{BghiP}>\mathrm{InP}>\operatorname{Cor}$ (Fig. 3). Ravindra et al. (2008) reported that increasing molecular weight with increasing carcinogenicity of the heavier PAHs. Thus, high relative abundance of HMW PAHs (Fig. 2) in some samples indicating high carcinogenic potency. Furthermore, particulate PAHs are considered to be significant hazardous substances to human health through inhaling due to their prolonged residence time in the natural environment. In particular, $\mathrm{BaP}$ has been recognized as being highly carcinogenic to people living there on long-run human exposure (Fang et al., 2004), uptake PAHs (e.g. BaP) with inhalation. Ravindra et al. (2008) also demonstrated that the first known chemical carcinogen material discovered so far is $\mathrm{BaP}$. The PAHs emission from biomass burning (wood, coal, and peat) is relatively predominant in the study area which is often conducted for diverse skin effects to human beings. The partial combustion of coal makes a significant contribution to the gross PAHs emission to the atmosphere worldwide (Ravindra et al., 2008). Accordingly, Boström et al. (2002) estimated that approximately $430 \mathrm{~kg}$ BaP has been generated from wood burning in Sweden during 1994, although gasoline and diesel vehicles combindly contribute much lower $\mathrm{BaP}(\sim 320 \mathrm{~kg})$. In the studied coals, BaP content ranged from 2 to $6 \%$ of the total PAHs and is the third highest in abundance among the carcinogenic PAHs (Fig. 3). This high $\mathrm{BaP}$ concentration in the particle phase may lead to elevate hazardous PAHs pool in the atmosphere. Additionally, Kumata et al. (2006) noted that biomass burning seems to contribute 17 to $45 \%$ of PAHs load of fine particles in residential areas of suburban Tokyo.

The potential health risk assessment of PAHs can be evaluated based on the toxic equivalency factors $\left(\mathrm{BaP}_{\mathrm{eq}}\right)$ (Kong et al., 2015; Li et al., 2016). The $\mathrm{BaP}_{\text {eq }}$ data for this study samples ranged from $0.55 \mathrm{ng} \mathrm{g}^{-1}$ to $6.51 \mathrm{ng} \mathrm{g}^{-1}$ (average $2.15 \mathrm{ng} \mathrm{g}^{-1}$ ), suggesting moderate to high health risk associated with exposure to PAHs in the atmospheric environment. The $\mathrm{BaP}$ contents in the samples are ranging from $0.04 \mathrm{ng} \mathrm{g}^{-1}$ to $3.41 \mathrm{ng} \mathrm{g}^{-1}$ (average $0.86 \mathrm{ng} \mathrm{g}^{-1}$ ), inferring 
Table I. Structure, formula, physicochemical properties and phase distribution of the studied PAHs (After ATSDR, 1995; Ravindra et al., 2008; Kim et al., 2013)

\begin{tabular}{|c|c|c|c|c|c|c|c|c|c|}
\hline Order & Compound name & Formula & $\begin{array}{l}\text { Mol. wt. } \\
\left(\mathrm{g} \mathrm{mol}^{-1}\right)\end{array}$ & $\begin{array}{l}\text { CAS } \\
\text { number }\end{array}$ & $\begin{array}{l}\text { Vapor pressure at } \\
25^{\circ} \mathrm{C}(\mathrm{Pa})\end{array}$ & $\begin{array}{l}\text { Melting point } \\
\left({ }^{\circ} \mathrm{C}\right)\end{array}$ & $\begin{array}{l}\text { Boiling point } \\
\left({ }^{\circ} \mathrm{C}\right)\end{array}$ & $\begin{array}{l}\text { Particle/gas phase } \\
\text { distribution }\end{array}$ & Structure \\
\hline 1 & Phenanthrene & $\mathrm{C}_{14} \mathrm{H}_{10}$ & 178 & $85-01-8$ & $9.07 \times 10^{-2}$ & 100 & $339-340$ & Particle gas phase & \\
\hline 2 & Anthracene & $\mathrm{C}_{14} \mathrm{H}_{10}$ & 178 & $120-12-7$ & $3.4 \times 10^{-3}$ & 218 & 340 & Particle gas phase & Oxy \\
\hline 3 & Fluoranthene & $\mathrm{C}_{16} \mathrm{H}_{10}$ & 202 & $206-44-0$ & $1.08 \times 10^{-3}$ & 107 & $375-393$ & Particle gas phase & \\
\hline 4 & Pyrene & $\mathrm{C}_{16} \mathrm{H}_{10}$ & 202 & $129-00-0$ & $5.67 \times 10^{-4}$ & 149 & $360-404$ & Particle gas phase & \\
\hline 5 & Retene & $\mathrm{C}_{18} \mathrm{H}_{18}$ & 219 & $483-65-8$ & $5.34 \times 10^{-6}$ & 98.5 & 390 & - & \\
\hline 6 & Benzo $[a]$ anthracene & $\mathrm{C}_{18} \mathrm{H}_{12}$ & 228 & $56-55-3$ & $6.52 \times 10^{-7}$ & 157 & 435 & Gas phase & \\
\hline 7 & Chrysene & $\mathrm{C}_{18} \mathrm{H}_{12}$ & 228 & $218-01-9$ & $1.04 \times 10^{-6}$ & 254 & $441-448$ & Gas phase & \\
\hline 8 & Benzo $[b, j, k]$ fluoranthene & $\mathrm{C}_{20} \mathrm{H}_{12}$ & 252 & $205-99-2$ & $1.07 \times 10^{-5}$ & 165 & 168 & Gas phase & \\
\hline 9 & Benzo $[e]$ pyrene & $\mathrm{C}_{20} \mathrm{H}_{12}$ & 252 & $192-97-2$ & $5.7 \times 10^{-9}$ & 179 & 495 & Gas phase & \\
\hline 10 & Benzo $[a]$ pyrene & $\mathrm{C}_{20} \mathrm{H}_{12}$ & 252 & $50-32-8$ & $6.52 \times 10^{-7}$ & 178 & $493-496$ & Gas phase & \\
\hline 11 & Indeno $[1,2,3-c d]$ pyrene & $\mathrm{C}_{22} \mathrm{H}_{12}$ & 276 & $193-39-5$ & $1.3 \times 10^{-10}$ & 164 & 162 & Gas phase & \\
\hline 12 & Benzo $[g, h, i]$ perylene & $\mathrm{C}_{22} \mathrm{H}_{12}$ & 276 & $191-24-2$ & $1.33 \times 10^{-8}$ & 278 & 525 & Gas phase & \\
\hline 13 & Coronene & $\mathrm{C}_{24} \mathrm{H}_{12}$ & 300 & $191-07-1$ & - & 438 & 525 & - & $\pi$ \\
\hline
\end{tabular}

Table II. Carcinogenic classifications of selected PAHs in airborne materials (PAHs data from ATSDR, 1995; USEPA, 2008; IARC, 2010; Kim et al., 2013)

\begin{tabular}{|c|c|c|c|c|}
\hline Order & Agency & PAH compounds & Carcinogenic classification & Reference \\
\hline 1 & $\begin{array}{l}\text { Agency for Toxic } \\
\text { Substances and Disease } \\
\text { Registry (ATSDR) }\end{array}$ & $\begin{array}{l}\text { Benzo[ } a \text { ]anthracene, } \\
\text { Benzo[ } b \text { ]fluoranthene, } \\
\text { Benzo[ } a \text { ]pyrene, } \\
\text { Dibenz } a, h \text { ]anthracene, }{ }^{*} \text { and } \\
\text { Indeno[1,2,3- } c d \text { ]pyrene } \\
\text { Benzo[ } a \text { ]anthracene and } \\
\text { Benzo[ } a \text { ]pyrene }\end{array}$ & $\begin{array}{l}\text { Known animal carcinogens } \\
\text { Probably carcinogenic to humans }\end{array}$ & ATSDR, 1995 \\
\hline 2 & $\begin{array}{l}\text { International Agency for } \\
\text { Research on Cancer (IARC) }\end{array}$ & $\begin{array}{l}\text { Benzo[ } a \text { ]fluoranthene, }{ }^{*} \\
\text { Benzo[ } k \text { ]fluoranthene, and } \\
\text { Indeno[1,2,3- } c d \text { ]pyrene } \\
\text { Anthracene, } \\
\text { Benzo[ } g h i \text { ]perylene, } \\
\text { Benzo[ } e \text { ]pyrene, } \\
\text { Chrysene, } \\
\text { Fluoranthene, } \\
\text { Fluorene,* } \\
\text { Phenanthrene, and } \\
\text { Pyrene }\end{array}$ & $\begin{array}{l}\text { Probably carcinogenic to humans } \\
\text { Not classifiable as to human carcinogenicity }\end{array}$ & IARC, 2010 \\
\hline 3 & $\begin{array}{l}\text { U.S. Environmental } \\
\text { Protection Agency (EPA) }\end{array}$ & $\begin{array}{l}\text { Benzo[a] anthracene, } \\
\text { Benzo[a]pyrene, } \\
\text { Benzo[ } b \text { ]fluoranthene, } \\
\text { Benzo[ } k \text { ]fluoranthene, } \\
\text { Chrysene, } \\
\text { Dibenz[ } a, h \text { ] anthracene, }{ }^{*} \text { and } \\
\text { Indeno[1,2,3- } c d \text { ]pyrene } \\
\text { Acenaphthylene,* } \\
\text { Anthracene, } \\
\text { Benzo[ ghi ]perylene, and } \\
\text { Fluoranthene }\end{array}$ & $\begin{array}{l}\text { Probably carcinogenic to humans } \\
\text { Not classifiable as to human carcinogenicity }\end{array}$ & USEPA, 2008 \\
\hline
\end{tabular}

\footnotetext{
* not analyzed in this study
} 
that the cancer risks of coal mine workers and surrounding habitants exposed to PAHs would be paid more attention. The estimated ILCR values for adults and children are ranged from $9.96 \times 10^{-5}$ to $1.27 \times 10^{-4}$ (average $8.44 \times 10^{-5}$ ) and 5.56 $\times 10^{-6}$ to $1.12 \times 10^{-6}$ (average $3.69 \times 10^{-6}$ ), respectively. In general, the ILCR values lower than or equal to $1.0 \times 10^{-6}$ are consider as negligible health risks, values range from $1.0 \times$ $10^{-6}$ to $1.0 \times 10^{-4}$ means potential health risks, and ILCR values over $1.0 \times 10^{-4}$ indicates high health risks to human (Bandowe and Nkansah, 2016; Hu et al., 2017). The overall ILCR values obtained in the present study imply that exposure of both adults and children to fine coal fractions from Barapukuria coal field area could lead to potential as well as high cancer risks. Meanwhile, peoples could be exposed to this toxic PAHs in the atmosphere are likely prone to adverse health effects when absorbed into their body over long periods of time. Therefore, it is essential to monitor the level of particulate PAHs in the Barapukuria coal mine area and in addition to the city region.

In the studied coals, carcinogenic PAHs are found in significant abundances (Fig. 3) having average ranged of 17 to $44 \%$ (Fig. 5). The result suggests high health risks for human exposed to these PAHs especially for coal mine workers and surrounding dwellers. However, high- or low-temperature coal combustion contributes $\sim 74$ to $80 \%$ total PAHs burden to the Czech Republic soils (Bosch et al., 2015). A coal-fired power plant also exist nearby the Barapukuria coal mine, releasing toxic PAHs to atmosphere might bear adverse health effect to adults as well as children residing surrounding regions. Kong et al. (2015) reported that coal-fired power plant may possibly emitted large amount of $\mathrm{BaP} / \mathrm{BeP}$ ratios for atmospheric particles. Therefore, extra precaution is urgently needed for controlling PAHs emission in the vicinity of Barapukuria coal mine and associated power station. The influx of PAHs in surrounding environments of the coal field areas should therefore be further investigated in response to ILCR of the coal mine workers and nearby citizens.

\section{Conclusions}

The PAHs in fine coal fractions from Barapukuria coal field in northwestern Bangladesh were examined to quantify their occurrence, distribution and possible human health impacts. A total of nine coal samples were analyzed using GC-MS. Among the PAHs, Flu, Pyr, Ret, Bflas, and BeP are significantly high, followed by Phe, InP, BghiP, and Cor representing that the PAHs were originated primarily from combustion sources, leading to probable carcinogenic to human beings. However, the biological origin of Phe and Ret are predominant their abundances, while combustion origin of Cor present in small amount. The average concentrations of carcinogenic PAHs in the coals are in decreasing order as follows: $\mathrm{Bflas}>\mathrm{BeP}>\mathrm{BaP}>\mathrm{BghiP}>$ $\mathrm{InP}>\mathrm{Cor}$. The ratios of $\mathrm{BeP} /(\mathrm{BeP}+\mathrm{BaP})$ ranging from 0.61 to 0.85 (average 0.74 ), reflecting decay of $\mathrm{BaP}$ due to ageing on prolonged exposure to solar radiation. $\mathrm{BaP} / \mathrm{BghiP}$ ratios ranged between $\sim 0.10$ and 6.16 (average 1.89) suggest occurrence of coaly organic matter. Correlation between $\mathrm{BaP}$ and Ant in the studied coals is marked negative ( $r=0.73$ ), increasing BaP with decreasing Ant implies that PAHs probably originated from different organic matter sources. The $\mathrm{BaP}_{\mathrm{eq}}$ values ranged from 0.55 $\mathrm{ng} \mathrm{g}^{-1}$ to $6.51 \mathrm{ng} \mathrm{g}^{-1}$ means the potential health risks of PAHs at the studied sites are perhaps highest. The ILCR values for adults $\left(9.96 \times 10^{-5}\right.$ to $\left.1.27 \times 10^{-4}\right)$ and children $\left(5.56 \times 10^{-6}\right.$ to $\left.1.12 \times 10^{-6}\right)$ are greater than or equal to the range of $1.0 \times 10^{-6}$ to $1.0 \times 10^{-4}$ indicates that the potential higher health risks to human living there. Therefore, the possible PAHs pollution in fine coal particles at the Barapukuria coal field area should be paid attention by the local environmental monitoring authority. However, further investigation of these coals with more extensive and comprehensive PAHs datasets will assist in increasing our understanding of the factors controlling carcinogenicity to human beings.

\section{Acknowledgment}

Authors would like to express our thanks to the authority of Barapukuria Coal Mining Company Limited (BCMCL) for their logistic support during field work. They are also grateful to the Associate Editor Dr. M. Sarwar Jahan and an anonymous referee for their valuable suggestions and comments, which significantly improved the revised manuscript.

\section{References}

Annual Report (2017), Annual Report 2016-2017, Barapukuria Coal Mining Company Limited (a Company of Petrobangla), p 95.

ATSDR (Agency for Toxic Substances, Disease Registry) (1995), Toxicological profile for polycyclic aromatic hydrocarbons, US Department of Health and Human Services 1995, US Government Printing Office: 1995-639-298.

Bakr MA, Rahman QMA, Islam MM, Islam MK, Uddin MN, 
Resan SA, Haider MJ, Islam MS, Ali MW, Chowdhury MEA, Mannan KM and Anam ANMH (1996), Geology and coal deposits of Barapukuria Basin, Dinajpur District, Bangladesh, Rec. Geol. Surv. Bangladseh 8: 42.

Bandowe BAM and Nkansah MA (2016), Occurrence, distribution and health risk from polycyclic aromatic compounds (PAHs, oxygenated-PAHs and azaarenes) in street dust from a major West African Metropolis, Sci. Total Environ. 553: 439-449. DOI:10. 1016/j.scitotenv.2016.02.142

Bosch C, Andersson A, Kruså M, Bandh C, Hovorková I, Klánová J, Knowles TDJ, Pancost RD, Evershed RP and Gustafsson Ö (2015), Source apportionment of polycyclic aromatic hydrocarbons in Central European soils with compound-specific triple isotopes $\left(\delta^{13} \mathrm{C}, \Delta\right.$ ${ }^{14} \mathrm{C}$, and $\left.\delta^{2} \mathrm{H}\right)$, Environ. Sci. Technol. 49: 7657-7665.

Boström C-E, Gerde P, Hanberg A, Jernström B, Johansson C, Kyrklund T, Rannug A, Törnqvist M, Victorin K and Westerholm R (2002), Cancer risk assessment, indicators, and guidelines for polycyclic aromatic hydrocarbons in the ambient air. Environ. Health Perspect. 110: 451-489.

Chefetz B, Deshmukh AP, Hatcher PG and Guthrie EA (2000), Pyrene sorption by natural organic matter, Environ. Sci. Technol. 34: 2925-2930. DOI: org/ 10.1021/es9912877

Fang G-C, Chang K-F, Lu C and Bai H (2004), Estimation of PAHs dry deposition and $\mathrm{BaP}$ toxic equivalency factors (TEFs) study at Urban, Industry Park and rural sampling sites in central Taiwan, Taichung, Chemosphere 55: 787-796.

Hossain HMZ, Islam MS, Ahmed SS and Hossain I (2002), Analysis of sedimentary facies and depositional environments of the Permian Gondwana sequence in borehole GDH-45, Khalaspir Basin, Bangladesh, Geosci. J. 6: 227-236.

Hossain HMZ, Sampei Y and Roser BP (2013a), Polycyclic aromatic hydrocarbons (PAHs) in late Eocene to early Pleistocene mudstones of the Sylhet succession, NE Bengal Basin, Bangladesh: Implications for source and paleoclimate conditions during Himalayan uplift, $\mathrm{Org}$. Geochem. 56: 25-39. DOI:org/10.1016/ j.orggeochem. 2012.12.001
Hossain HMZ, Sampei Y, Hossain QH, Roser BP and Islam MS (2013b), Characterization of alkyl phenanthrene distributions in Permian Gondwana coals and coaly shales from the Barapukuria Basin, NW Bangladesh, Res. Org. Geochem. 29: 17-28.

Hossain HMZ, Sampei Y, Hossain QH, Yamanaka T, Roser BP and Islam MS (2019), Origin of organic matter and hydrocarbon potential of Permian Gondwana coaly shales intercalated in coals/sands of the Barapukuria basin, Bangladesh, Int. J. Coal Geol. (In Press).

Hu T, Zhang J, Ye C, Zhang L, Xing X, Zhang Y, Wang Y, Sun W, Qi S and Zhang Q (2017), Status, source and health risk assessment of polycyclic aromatic hydrocarbons (PAHs) in soil fromthewater-level-fluctuation zone of the Three Gorges Reservoir, China, J. Geochem. Explor. 172: 20-28.

Huang XF, He LY, Hu M and Zhang YH (2006), Annual variation of particulate organic compounds in $\mathrm{PM}_{2.5}$ in the urban atmosphere of Beijing, Atmos. Environ. 40: 2449-2458. DOI:org/10.1016/j.atmosenv.2005.12.039

IARC (International Agency for Research on Cancer) (2010), Some non-heterocyclic polycyclic aromatic hydrocarbons and some related exposures, Monogr. Eval. Carcinog. Risks Hum. 92: 765-71.

Islam MS (1993), Anatomy and depositional environment of the abnormally thick coal seam VI in the Barapukuria basin, Dinajpur, Bangladesh, Bangladesh J. Geol. 12: 27-38.

Islam MS (1994), Gondwana coal resources of Bangladesh and their characteristics, Proceedings of Second SEGMITE International Conference, Pakistan, pp 85-90.

Islam MS (2002), Stratigraphy and sedimentology of the Gondwana rocks in the Barapukuria basin, Dinajpur district, Bangladesh, $P h D$ Thesis, Jahangirnagar University.

Islam MS, Chowdhury KR and Ishiga H (2004), Geochemistry of the Gondwana sedimentary rocks from the Barapukuria basin, Bangladesh, Bangladesh Geosci. J. 10: 83-102.

Jamhari AA, Sahani M, Latif MT, Chan K, Tan H, Khan MF and Tahir NM (2014), Concentration and source identification of polycyclic aromatic hydrocarbons 
(PAHs) in $\mathrm{PM}_{10}$ of urban, industrial and semi-urban areas in Malaysia, Atmos. Environ. 86: 16-27. DOI:org/10.1016/j.atmosenv.2013.12.019

Jiang C, Alexander R, Kagi RI and Murray AP (1998), Polycyclic aromatic hydrocarbons in ancient sediments and their relationships to palaeoclimate, Org. Geochem. 29: 1721-1735.

Kim KH, Jahan SA, Kabir E and Brown RJC (2013), A review of airborne polycyclic aromatic hydrocarbons (PAHs) and their human health effects, Environ. Int. 60: 71-80. DOI: org/10.1016/j.envint.2013.07.019

Kong S, Li X, Li L, Yin Y, Chen K, Yuan L, Zhang Y, Shan Y and Ji Y (2015), Variation of polycyclic aromatic hydrocarbons in atmospheric $\mathrm{PM}_{2.5}$ during winter haze period around 2014 Chinese Spring Festival at Nanjing: Insights of source changes, air mass direction and firework particle injection, Sci. Total Environ. 520: 59-72. DOI: org/10.1016/j.scitotenv.2015.03.001

Kumata H, Uchida M, Sakuma E, Uchida T, Fujiwara K, Tsuzuki M, Yoneda M and Shibata Y (2006), Compound class specific C-14 analysis of polycyclic aromatic hydrocarbons associated with $\mathrm{PM}_{10}$ and $\mathrm{PM}_{1.1}$ aerosols from residential areas of suburban Tokyo, Environ. Sci. Technol. 40: 3474-3480.

Li X, Kong S, Yin Y, Li L, Yuan L, Li Q, Xiao H and Chen K (2016), Polycyclic aromatic hydrocarbons (PAHs) in atmospheric $\mathrm{PM}_{2.5}$ around 2013 Asian Youth Games period in Nanjing, Atmos. Res. 174-175: 85-96.

Liu B, Xue Z, Zhu X and Jia C (2017), Long-term trends (1990-2014), health risks, and sources of atmospheric polycyclic aromatic hydrocarbons (PAHs) in the U.S., Environ. Pollut. 220: 1171-1179.

Lui KH, Bandowe BAM, Tian L, Chan Chi-S, Cao J-J, Ning Z, Lee SC and Ho KF (2017), Cancer risk from polycyclic aromatic compounds in fine particulate matter generated from household coal combustion in Xuanwei, China, Chemosphere 169: 660-668. DOI:org/10.1016/j.chemosphere.2016.11.112

Marynowski L, Szelęg E, Jędrysek MO and Simoneit BRT (2011), Effects of weathering on organic matter Part II: Fossil wood weathering and implications for organic geochemical and petrographic studies, Org. Geochem. 42: 1076-1088. DOI:org/10.1016/ j.orggeochem. 2011.06.017
Mulder MD, Heil A, Kukucka P, Kuta J, Pribylova P, Prokes $\mathrm{R}$ and Lammel G (2015), Long-range atmospheric transport of PAHs, PCBs and PBDEs to the central and eastern Mediterranean and changes of PCB and PBDE congener patterns in summer 2010, Atmos. Environ. 111: 51-59.

Nielsen T (1988), The decay of benzo(a)pyrene and cyclopenteno $(c d)$ pyrene in the atmosphere, Atmos. Environ. 22: 2249-2254.

Omar NYMJ, Mon TC, Rahman NA and Abas MRB (2006), Distributions and health risks of polycyclic aromatic hydrocarbons (PAHs) in atmospheric aerosols of Kuala Lumpur, Malaysia, Sci. Total Environ. 369: 76-81.

Ravindra K, Sokhi R and Grieken RV (2008), Review: atmospheric polycyclic aromatic hydrocarbons: source attribution, emission factors and regulation, Atmos. Environ. 42: 2895-2921.

Sicre MA, Marty JC and Saliot A (1987), Aliphatic and aromatic hydrocarbons in different sized aerosols over the Mediterranean Sea: Occurrence and origin, Atmos. Environ. 21: 2247-2259.

Stout SA and Emsbo-Mattingly SD (2008), Concentration and character of PAHs and other hydrocarbons in coals of varying rank - implications for environmental studies of soils and sediments containing particulate coal, Org. Geochem. 39: 801-819. DOI: org/10.1016/j. orggeochem.2008.04.017

Tahsin S, Hossain HMZ and Hossain MM (2016), Organic matter in coal seam-VI of the Barapukuria coal field in Bangladesh, Bangladesh J. Sci. Ind. Res. 51(3): 221-230.

Uddin N and Islam MS (1992), Gondwana basins and their coal resources in Bangladesh. Proceedings of the First South Asian Geological Congress, (GEOSAS-1), published in 1994, pp 224-230.

USEPA (United States Environmental Protection Agency) (1989), Risk Assessment Guidance for Superfund, EPA 540-1-89-002, Human Health Evaluation Manual (Part A), vol. I, Office of Emergency and Remedial Response (accessed 10.09.13.).

USEPA (United States Environmental Protection Agency) (2008), Polycyclic aromatic hydrocarbons (PAHs) -EPA fact sheet, Washington, DC: National Center for 
Environmental Assessment, Office of Research and Development.

USEPA (United States Environmental Protection Agency) (2013), Available from: http://www.epa.gov/ reg3hwmd/risk/human (accessed 10 September 2013).

Vicente ED, Vicente AM, Bandowe BAM and Alves CA (2015), Particulate phase emission of parent polycyclic aromatic hydrocarbons (PAHs) and their derivatives (alkyl-PAHs, oxygenated-PAHs, azaarenes and nitrated PAHs) from manually and automatically fired combustion appliance, Air Qual. Atmos. Health 9: 653-668.

Wardell-Armstrong Ltd. (1991), Techno-economic feasibility study, Barapukuria coal project, Dinajpur, Bangladesh, 12 volumes, Report submitted to Ministry of Energy and Mineral Resources, Government of People's Republic of Bangladesh (unpublished). DOI: org/10.1016/ j.coal.2008.05.008

Wincent E, Le Bihanic F and Dreij K (2016), Induction and inhibition of human cytochrome $\mathrm{P} 4501$ by oxygenated polycyclic aromatic hydrocarbons, Toxicol. Res. 5: 788-799.
Wiriya W, Prapamontol T and Chantara S (2013), PM10-bound polycyclic aromatic hydrocarbons in Chiang Mai (Thailand): seasonal variations, source identification, health risk assessment and their relationship to air-mass movement, Atmos. Res. 124: 109-122. DOI: org/10.1016/j.atmosres.2012.12.014

Wu D, Wang Z, Chen J, Kong S, Fu X, Deng H, Shao G and Wu G (2014), Polycyclic aromatic hydrocarbons (PAHs) in atmospheric $\mathrm{PM}_{2.5}$ and $\mathrm{PM}_{10}$ at a coal-based industrial city: Implication for PAH control at industrial agglomeration regions, China, Atmos. Res. 149: 217-229.

Yunker MB, Lachmuth CL, Cretney WJ, Fowler BR, Dangerfield N, White L and Ross PS (2011), Biota-sediment partitioning of aluminium smelter related PAHs and pulp mill related diterpenes by intertidal clams at Kitimat, British Columbia, Mar. Environ. Res. 72: 105-126. DOI: org/10.1016/ j.marenvres.2011.06.004

Yunker MB, Macdonald RW, Vingarzan R, Mitchell RH, Goyette D and Sylvestre S (2002), PAHs in the Fraser River basin: a critical appraisal of $\mathrm{PAH}$ ratios as indicators of $\mathrm{PAH}$ source and composition, Org. Geochem. 33: 489-515. 